\title{
Antitumor Effects and Pharmacological Interaction of Xiao-Chai-Hu-Tang (Sho-Saiko-To) and Interleukin 2 in Murine Renal Cell Carcinoma
}

\author{
Yongping Huang, Ken Marumo and Masaru Murai \\ Department of Urology, School of Medicine, Keio University, Tokyo, Japan
}

(Received for publication on March 17, 1997)

\begin{abstract}
Conventional therapy for renal cell carcinoma using interleukin 2 (IL-2) has shown limited antitumor action. The purpose of our study was to investigate synergistic antitumor effects of IL-2 and Xiao-Chai-Hu-Tang (XCHT), and to elucidate the mechanisms of interaction between the two drugs against the murine renal cell carcinoma cell line, Renca, in vivo. The treatment was started 5 days after subcutaneous transplantation of Renca tumor. XCHT was given at a dose of $2.5 \mathrm{~g} / \mathrm{kg}$ daily for 30 days orally. IL-2 was given at a dose of $10^{4} \mathrm{U} /$ mouse by subcutaneous injection every other day 8 times. Combination of XCHT and IL-2 inhibited growth of the tumor and prolonged survival significantly as compared with the untreated mice. Increased cellular infiltration was observed in tumor tissue and the lungs of mice treated with XCHT alone and by combination of XCHT and $\mathrm{L-2}$, but there were no histological changes in the liver and kidney. Elevation of serum IL-6 was observed in tumor-bearing mice, but IL-6 was significantly suppressed by administration of XCHT. The results obtained suggest that combination of XCHT and IL-2 induces enhanced immunological reaction in specific organs and tissues, and IL-6 may have a role in the synergistic effect of these two agents. It was concluded that combination of XCHT and IL-2 is useful in the treatment of patients with renal cell carcinoma. (Keio I Med 46 (3): 132-137, September 1997)
\end{abstract}

Key words: Xiao-Chai-Hu-Tang, interleukin 2, interleukin 6, Sino-Japanese medicine, renal cell carcinoma

Introduction

Renal cell carcinoma is a relatively common tumor, accounting for approximately $3 \%$ of adult malignancies. ${ }^{1}$ Currently, the only chance for cure of renal cell carcinoma is early detection and surgical resection. However, approximately $30 \%$ of patients have metastatic disease at the time of diagnosis, and $50 \%$ of those treated for cure by radical nephrectomy eventually develop either local recurrence or distant metastases. ${ }^{2}$ Once the disease has become metastatic or recurrent, renal cell carcinoma carries a poor prognosis with $74 \%$ mortality at 1 year and $96 \%$ mortality at 3 years. ${ }^{3}$ This is due to the absence of effective therapy for patients with advanced renal cell carcinoma. None of the hor- monal or chemotherapeutic agents so far tested has given an objective response rate greater than $15 \%$ by monotherapy.

Interleukin 2 (IL-2), originally discovered as a T-cell growth factor, is a lymphokine produced by helper $\mathrm{T}$ lymphocytes. ${ }^{4}$ Treatment of tumor-bearing mice or patients with IL-2 alone, or combined with the adoptive transfer of lymphocytes activated by IL-2, has been shown to induce regression of the tumors. ${ }^{5-7}$ However, conventional systemic IL-2 therapy has shown only limited anti-tumor activity.

Xiao-Chai-Hu-Tang (XCHT) is a traditional Chinese medicine composed of hot water extracts from 7 species of medical plants, Bupleuri Radix, Pinelliae Tuber, Scutellariae Radix, Zizyphi Fructus, Ginseng Radix,

黄 永平, 九茂 健, 村井 勝

Reprint requests to: Dr Ken Marumo, Department of Urology, School of Medicine, Keio University, 35 Shinanomachi, Shinjuku-ku, Tokyo 160, Japan 
Glycyrrhizae Radix and Zingiberis Rhizoma, and has been used as an antipyretic medicine. A recent study utilizing biochemical technology disclosed that XCHT has various pharmacological actions including antiinflammatory, anti-viral, immunomodulating effects, ${ }^{8,9}$ and has been shown to have an anti-tumor activity as a biological response modifier property. ${ }^{10}$

The purpose of our study was to investigate synergistic antitumor effects of IL-2 and XCHT, and elucidate the mechanisms of interaction between the two drugs in murine renal cell carcinoma cell line.

\section{Materials and Methods}

\section{Animals}

Female BALB/c mice were purchased from Charles River Japan Inc. (Kanagawa, Japan). The animals were kept in established pathogen-free condition animal cages and fed a commercial pellet diet CE-2 (CLEA Inc., Tokyo, Japan). For all experiments, 6-week-old mice were used.

\section{Tumor cells}

Renca, which is a transplantable murine renal cell carcinoma of spontaneous origin, was established at the National Cancer Institute, USA, ${ }^{11}$ and was a generous gift from $\mathrm{Dr} T$ Fujioka (Iwate Medical University, Morioka, Japan).

\section{Tumor transplantation}

The masses of Renca tumors were excised from mice and cut into about $3 \mathrm{~mm} \times 3 \mathrm{~mm} \times 3 \mathrm{~mm}$ pieces. Then each fragment was implanted subcutaneously into the back of a mouse with a trocar needle.

\section{Interleukin 2}

The recombinant human IL-2 was produced by Shionogi \& Co. Ltd. (Osaka, Japan). The titer of the IL-2 was evaluated via ${ }^{3} \mathrm{H}$-thymidine incorporation of the CTLL-2 cell line and expressed in Japan reference units.

\section{Xiao-Chai-Hu-Tang}

XCHT (Sho-saiko-to ${ }^{\circledR}$ ), was obtained from Tsumura \& Co. Ltd. (Tokyo, Japan). It was prepared by boiling 7 authenticated herbal drugs with hot distilled water in the following proportions: $7.0 \mathrm{~g}$ Bupleuri Radix, $5.0 \mathrm{~g}$ Pinelliae Tuber, $3.0 \mathrm{~g}$ Scutellariae Radix, $3.0 \mathrm{~g}$ Zizyphi Fructus, $3.0 \mathrm{~g}$ Ginseng Radix, $2.0 \mathrm{~g}$ Glycyrrhizae Radix and $1.0 \mathrm{~g}$ Zingiberis Rhizoma. Aqueous extract was fil- tered, spray-dried, and $4.5 \mathrm{~g}$ of spray dried extract is equivalent to the human daily dose of decoction. This extract was stored at $4^{\circ} \mathrm{C}$ until redissolution in distilled water at a concentration of $1 \mathrm{~g} / 100 \mathrm{ml}$ for use. XCHT was almost soluble in water and the solution with a small amount of insoluble debris was provided to mice as drinking water for 30 days ad libitum.

\section{Experimental therapy model}

Five days after tumor implantation, mice were separated into groups consisting of seven mice each after randomization and therapy was started. IL-2 was dissolved in phosphate-buffered saline (PBS) and a $0.2 \mathrm{ml}$ portion of the solution was administered by subcutaneous injection at a dose of $10^{4} \mathrm{U} /$ mouse every other day, 8 times. The dose of IL-2 for combination therapy with XCHT was established as a minimal but significantly effective dose from a dose-finding test with doses varying from $5 \times 10^{3} \mathrm{U} /$ mouse to $5 \times 10^{4} \mathrm{U} /$ mouse. $\mathrm{XCHT}$ was given to the mice as drinking water daily for 30 days. The perpendicular diameters of the tumors were measured with a sliding caliper and the tumor weights were estimated by the formula, (long diameter) $\times(\text { short diameter })^{2} / 2$.

\section{IL-6 determination}

IL-6 levels in the serum were measured by an enzyme-linked immunosorbent assay (ELISA). Ten days after initiation of treatment with XCHT and/or IL-2, blood was taken from the retroorbital sinus. The serum was subjected to ELISA for the determination of IL-6 using a Cytoscreen ${ }^{\text {TM }}$ mouse IL-6 Kit (BioSourse International, Camarillo, CA, USA). The concentration of IL- 6 was given as the average level from four mice.

\section{Histopathological analysis}

Histopathological changes of the tumor were analyzed in 4 groups, including untreated mice, consisting of 3 mice each. Mice were sacrificed by decapitation under light ether anesthesia 10 days after initiation of the treatment with IL-2 and/or XCHT, and the tumors, lungs, livers and kidneys were resected, fixed and stained with hematoxylin-eosin.

\section{Statistical analysis}

Statistical analyses were carried out based on growth ratios to tumor volumes before treatment in each group using the Student's t-test. Survival rates were calculated by the Kaplan-Meier method and the statistics determined by the Wilcoxon rank sum test. A $P$ value of less than 0.05 was considered statistically significant. 


\section{Results}

\section{Daily dose of XCHT}

The aqueous solution of XCHT was exchanged every second or third day and the consumption was measured. The average daily intake of this solution by each mouse was $4.9 \mathrm{ml}$ for the 15 days after initiation of the therapy, and the daily dose of XCHT was calculated to be $2.5 \mathrm{~g} / \mathrm{kg}$ from weights of mice at the initiation of the treatment. Water consumption was not influenced by addition of XCHT to drinking water.

\section{Antitumor activity}

Dose dependent antitumor effects are shown in Table 1. IL-2 at a dose of $5 \times 10^{3} \mathrm{U} /$ mouse had a tendency to inhibit growth of the tumor, however, it was not significant. On the other hand, IL-2 at doses of $1 \times 10^{4} \mathrm{U} /$ mouse and $5 \times 10^{4} \mathrm{U} /$ mouse significantly inhibited growth of the Renca tumor $(\mathrm{P}<0.05)$. Based on the result of the dose finding test, $1 \times 10^{4} \mathrm{U} /$ mouse of IL-2 was employed in combination therapy with XCHT.

Effects of XCHT and IL-2 on the growth of the tumor are shown in Table 2. XCHT did not significantly inhibit growth of the tumor. IL-2 significantly inhibited growth of the tumor $(P<0.05)$. The antitumor effect was most pronounced in the mice treated with the combination of XCHT and IL-2, and was significantly different compared to mice treated with XCHT or IL-2 alone $(\mathrm{P}<0.05)$. XCHT and IL-2 are considered to have a synergistic antitumor effect when $\mathrm{T} / \mathrm{C}$ value of mice treated with $\mathrm{XCHT}(83 \%) \times \mathrm{T} / \mathrm{C}$ value of mice treated with IL-2 $(68 \%)$ is greater than that of mice treated with both drugs in combination, where $T$ is mean tumor weight of the treated mice and $C$ is mean tumor weight of the untreated mice. Fifteen days after initiation of treatment, the $\mathrm{T} / \mathrm{C}$ value of mice treated with $\mathrm{XCHT} \times \mathrm{T} / \mathrm{C}$ value of mice treated with IL-2 was 56.4. On the other hand, the $\mathrm{T} / \mathrm{C}$ value of mice treated with both drugs in combination was 21.1. Results showed that the combination of XCHT and IL-2 has a synergistic antitumor effect.

Treatment with XCHT or IL-2 alone did not extend the survival of mice, but survival was significantly $(\mathrm{P}<0.05)$ extended in mice treated with both drugs in combination (Fig 1).

\section{Serum $I L-6$}

IL- 6 concentrations in the serum were determined by ELISA in non tumor-bearing mice and tumor bearing mice treated with XCHT and/or IL-2. IL-6 was undetectable in mice to which Renca tumor had not been
Table 1 Effects of Interleukin 2 on the Growth of Renca Tumor (Murine Renal Cell Carcinoma) in Mice

\begin{tabular}{lllll}
\hline \hline Treatment* & \multicolumn{4}{c}{ Tumor Weight (mg) } \\
\cline { 2 - 5 } & $\begin{array}{c}\text { Before } \\
\text { Treatment }\end{array}$ & \multicolumn{2}{l}{ Days after Initiation of Treatment } \\
\cline { 2 - 5 } & & 7 Days & 11 Days & 15 Days \\
\hline Untreated & $18 \pm 3$ & $93 \pm 10$ & $246 \pm 34$ & $602 \pm 87$ \\
IL-2 $5 \times 10^{3} \mathrm{U}$ & $19 \pm 3$ & $76 \pm 10$ & $162 \pm 22$ & $489 \pm 55$ \\
IL-2 $1 \times 10^{4} \mathrm{U}$ & $17 \pm 2$ & $55 \pm 9 \neq$ & $117 \pm 24^{\S}$ & $384 \pm 55^{\S}$ \\
IL-2 $5 \times 10^{4} \mathrm{U}$ & $18 \pm 2$ & $43 \pm 9^{\ddagger}$ & $84 \pm 14^{\S}$ & $258 \pm 34^{\S}$ \\
\hline
\end{tabular}

Table values are mean \pm SE for 7 mice; * interleukin 2 (IL-2) was administered subcutaneously every other day 8 times at a dose of $5 \times 10^{3}, 1 \times 10^{4}$ or $5 \times 10^{4} \mathrm{U} /$ mouse; ${ }^{\ddagger} \mathrm{p}<0.05$ vs control; ${ }^{\S} \mathrm{p}<0.01$ vs control.

Table 2 Effects of Xiao-Chai-Hu-Tang (XCHT) and/or Interleukin 2 (IL-2) on the Growth of Renca Tumor (Murine Renal Cell Carcinoma) in Mice

\begin{tabular}{|c|c|c|c|c|}
\hline \multirow[t]{3}{*}{ Treatment* } & \multicolumn{4}{|c|}{ Tumor Weight (mg) } \\
\hline & \multirow{2}{*}{$\begin{array}{c}\text { Before } \\
\text { Treatment }\end{array}$} & \multicolumn{3}{|c|}{ Days after Initiation of Treatment } \\
\hline & & 7 Days & 11 Days & 15 Days \\
\hline Untreated & $14 \pm 6$ & $82 \pm 12$ & $213 \pm 54$ & $578 \pm 158$ \\
\hline $\mathrm{XCHT}$ & $13 \pm 3$ & $39 \pm 8$ & $130 \pm 21$ & $478 \pm 62$ \\
\hline IL-2 & $13 \pm 4$ & $46 \pm 11$ & $76 \pm 12^{\dagger}$ & $391 \pm 109^{\dagger}$ \\
\hline $\begin{array}{l}\mathrm{XCHT} \text { and } \\
\text { IL-2 }\end{array}$ & $14 \pm 4$ & $13 \pm 5^{\dagger}$ & $38 \pm 14^{t \hbar \S}$ & $122 \pm 25^{\dagger \neq \S}$ \\
\hline
\end{tabular}

Table values are mean \pm SE for 7 mice; ${ }^{* X C H T}$ was administered orally daily, for 30 days, at a dose of $2.5 \mathrm{~g} / \mathrm{kg} /$ day; IL-2 was administered subcutaneously every other day, 8 times, at a dose of $10^{4}$ $\mathrm{U} /$ mouse. ${ }^{\dagger} \mathrm{p}<0.05$ vs control; ${ }^{\ddagger} \mathrm{p}<0.05$ vs XCHT; ${ }^{\S} \mathrm{p}<0.05$ vs IL-2.

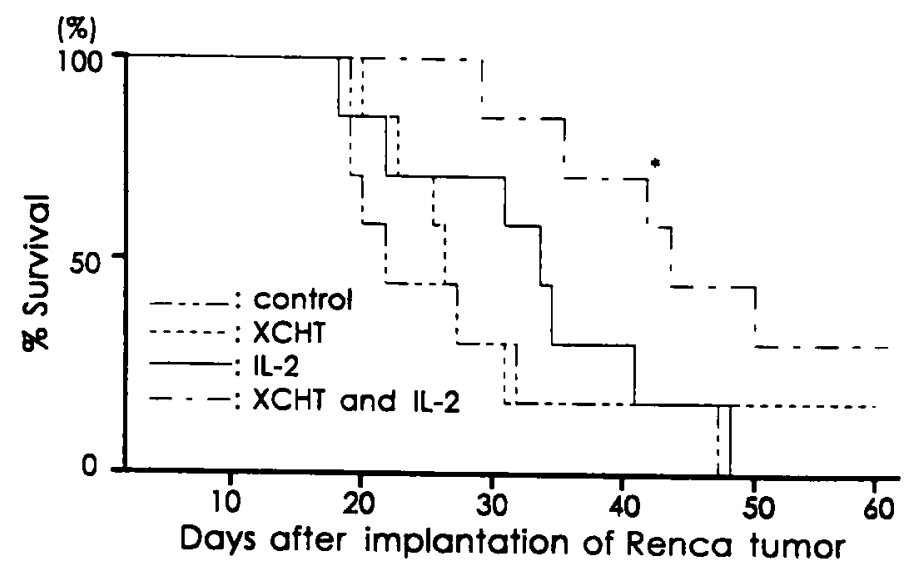

Fig 1 Survival of mice treated with XCHT and/or interleukin 2 (IL-2). * Significantly different when compared to control mice tested by the Wilcoxon rank sum test. 
transplanted. IL-6 concentrations were significantly lower in mice treated with XCHT alone than in untreated tumor-bearing mice. Serum IL-6 concentrations decreased by administration of IL-2 alone or combination of XCHT and IL-2 but there was no significant difference compared with untreated tumorbearing mice. Ratios of IL- 6 concentration to tumor weights were then compared between each treatment group. The ratio in mice treated with XCHT alone was much lower than that in mice of other treatment groups (Table 3).

Table 3 Serum Interleukin 6 (IL-6) Levels of Mice Treated by $\mathrm{XCHT}$ and/or Interleukin 2 (IL-2)

\begin{tabular}{lccc}
\hline Treatment* & IL-6 (pg/ml) & $\begin{array}{c}\text { Tumor } \\
\text { Weight (mg) }\end{array}$ & $\begin{array}{c}\text { Ratio of IL-6 } \\
\text { Level to Tumor } \\
\text { Weight }\end{array}$ \\
\hline $\begin{array}{l}\text { Untreated } \\
\text { (tumor }-)\end{array}$ & 0 & 0 & - \\
$\begin{array}{l}\text { Untreated } \\
\text { (tumor }+)\end{array}$ & $122.8 \pm 47.2$ & $179.5 \pm 33.4$ & $0.67 \pm 0.15$ \\
XCHT & $25.2 \pm 14.3^{\dagger \ddagger}$ & $136.3 \pm 40.5$ & $0.18 \pm 0.06^{\dagger \ddagger}$ \\
IL-2 & $88.5 \pm 23.3^{\S}$ & $96.3 \pm 36.0$ & $0.96 \pm 0.16^{\S}$ \\
XCHT and & $50.5 \pm 32.1$ & $54.5 \pm 12.1$ & $0.88 \pm 0.40^{\S}$ \\
IL-2 & & & \\
\hline
\end{tabular}

Table values are mean \pm SD for 4 mice; ${ }^{*} \mathrm{XCHT}$ was administered orally daily, for 10 days, at a dose of $2.5 \mathrm{~g} / \mathrm{kg} /$ day; IL-2 was administered subcutaneously every other day, 5 times, at a dose of $10^{4}$ $\mathrm{U} /$ mouse. Blood was collected 10 days after initiation of the therapy. ${ }^{\dagger} \mathrm{p}<0.05$ vs untreated tumor-bearing mice; ${ }^{\ddagger} \mathrm{p}<0.05$ vs IL-2; ${ }^{8} \mathrm{p}<$ 0.05 vs XCHT.

\section{Histopathological analysis}

Tumors, lungs, livers and kidneys were removed ten days after initiation of treatment and stained with hematoxylin-eosin. In the tumors of mice treated with XCHT, IL-2 or combination of XCHT and IL-2, enlargement of nuclei and loosened intercellular connection of tumor cells were observed. Marked cellular infiltration and scattered loss of tumor cells were observed in mice treated by combination of XCHT and IL-2 (Fig 2). Cellular infiltration and alveolar wall thickening were observed in the lungs of mice treated with XCHT and in mice treated with the combination of XCHT and IL-2 (Fig 3), but there were no histological changes in the liver and kidney (data not shown).

\section{Discussion}

Recently, it has been generally recognized that $\mathrm{XCHT}$ has a biological response modifier property. $\mathrm{XCHT}$ was shown to increase pokeweed mitogeninduced production of IL-1 $\beta$, IL- 6 and granulocytemacrophage colony-stimulating factor (GM-CSF) by human peripheral blood mononuclear cells in vitro, ${ }^{12}$ and oral administration of XCHT augments natural killer (NK) activity in mice. ${ }^{13}$ We have expected that $\mathrm{XCHT}$ would have antitumor action in combination with IL-2 against renal cell carcinoma by activation of cytokine network of tumor-bearing animals or human. The present study has demonstrated that $\mathrm{XCHT}$ and IL-2 have a synergistic antitumor effect against Renca

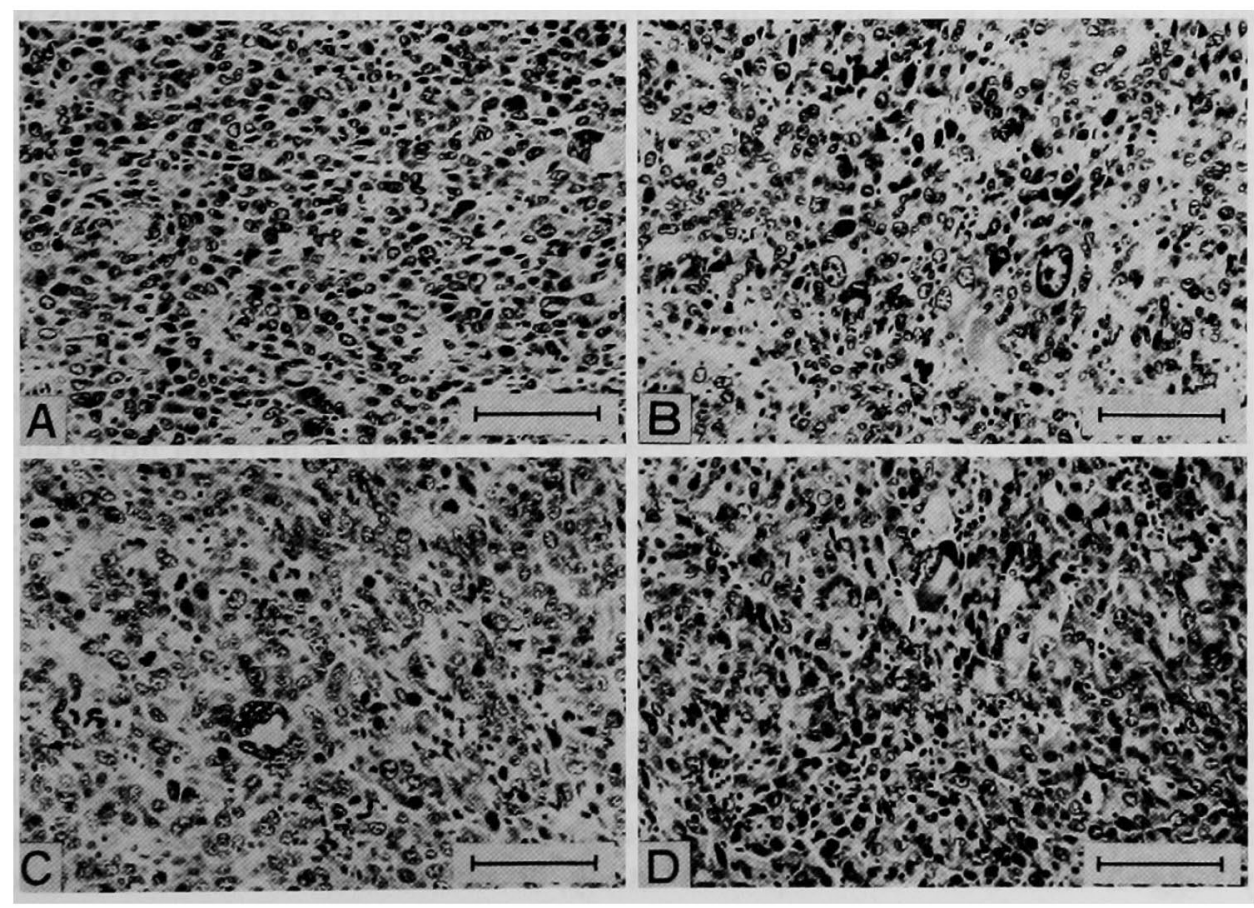

Fig 2 Hematoxylin-eosin staining of tumor in mice $\mathbf{1 0}$ days after initiation of the therapy. (A) control mice, (B) mice treated with XCHT, (C) mice treated with interleukin 2 (IL-2), (D) mice treated with combination of XCHT and IL-2. Bar $=100 \mu \mathrm{m}$. 


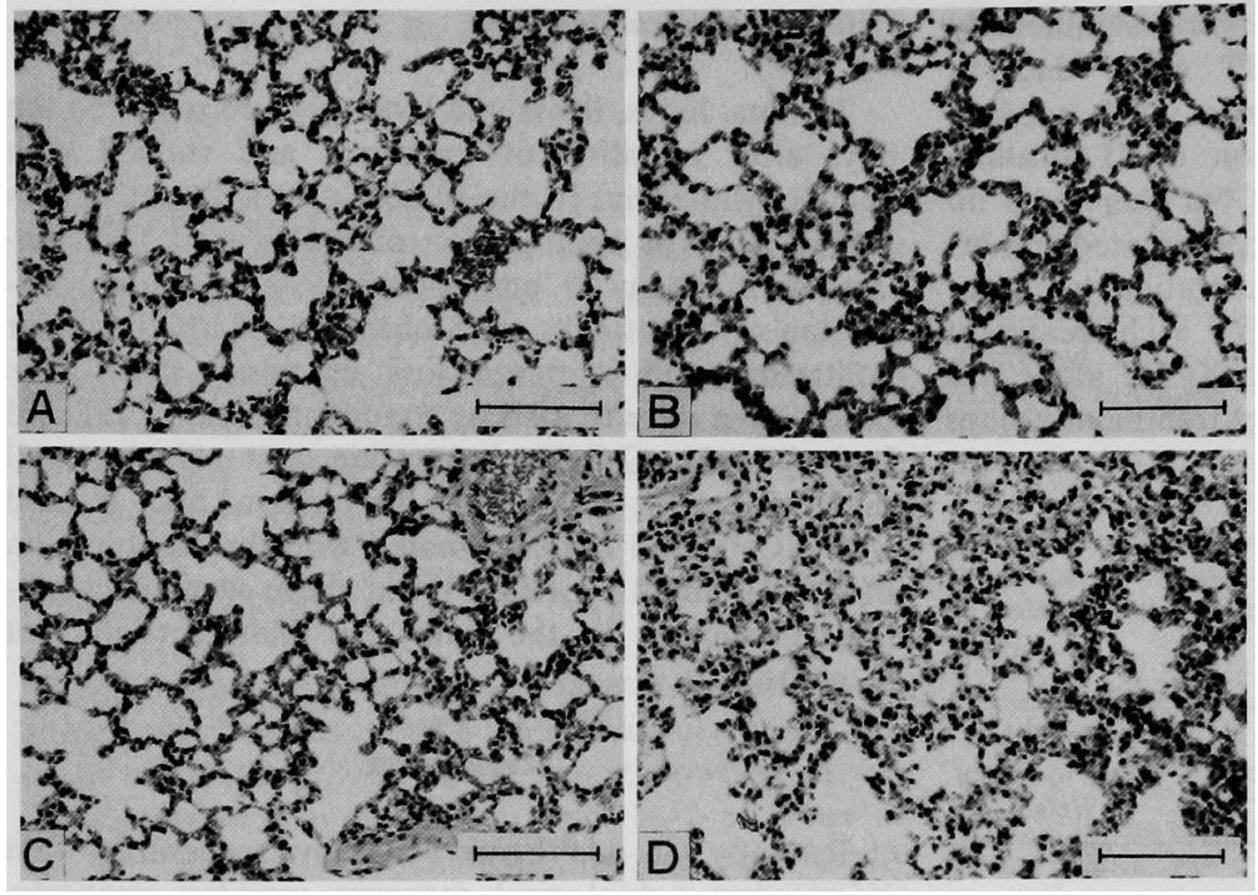

Fig 3 Hematoxylin-eosin staining of lungs in mice 10 days after initiation of the therapy. (A) control mice, (B) mice treated with XCHT, (C) mice treated with interleukin 2 (IL-2), (D) mice treated with combination of XCHT and IL-2. Bar $=100 \mu \mathrm{m}$. tumor and prolong survival of tumor-bearing mice.

Hematoxylin-eosin staining of the livers and kidneys of mice treated with IL-2, XCHT, or combination of the two drugs showed no histopathological changes, in contrast, increased cellular infiltration was observed in tumor tissue and the lungs of mice treated with XCHT or by combination of XCHT and IL-2, despite our having avoided cervical dislocation or use of heavy anesthetics for sacrifice of the mice because these procedures may cause lung congestion. ${ }^{14}$

It has been reported that pulmonary fibrosis following interstitial pneumonia is a serious side effect of concomitant administration of interferon (IFN) and $\mathrm{XCHT}$ administered to the patients with chronic active hepatitis. ${ }^{15}$ It has not been clarified whether IFN participates in development of pulmonary fibrosis by allergic reaction or pharmacological action of IFN itself, but Elias $e t a^{16}$ demonstrated that IFN controls proliferation of human fibroblasts in vitro. Interstitial pneumonia caused by XCHT alone has been reported, and Tomioka ${ }^{17}$ suggested that this side effect was caused by allergic reaction to $\mathrm{XCHT}$, analyzing bronchoalveolar lavage fluid and specimens obtained by transbronchial lung biopsy of the patient. Therefore, IFN and XCHT are considered to cause biological changes of the lung by additive effects. On the other hand. IL-2 is known to be an IFN-inducer. Handa $e t$ al demonstrated that IL-2 stimulates NK clones to proliferate, accompanied by IFN- $\gamma$ production in the culture fluid. ${ }^{18}$ These reports may explain the histopathological changes observed in the lungs of mice treated with IL- 2 and XCHT in the present study. Furthermore, it may suggest that con- comitant use of XCHT and IFN, or IL-2, which is known to be an IFN-inducer, would enhance immunological reaction in the specific organs or tissue, including the lungs and tumor tissue.

IL-6 was detected in the sera of mice bearing Renca tumor. This elevation of serum IL-6 is considered to be due to production of IL- 6 by Renca tumor itself or by host immune mediating cells in the results of reaction with tumor cells and IL-6, originally identified as a B cell stimulatory factor (BSF-2), ${ }^{19}$ has been demonstrated to have a variety of biological functions. IL-6 induces the terminal maturation of activated $B$ cells to immunoglobulin-producing cells derived from $\mathbf{T}$ lymphocytes, ${ }^{19}$ stimulates acute phase protein synthesis in hepatocytes, ${ }^{20}$ acts on multipotential hematopoietic progenitors, ${ }^{21}$ and was shown to be an autocrine growth factor for human multiple myeloma ${ }^{22}$ and renal cell carcinoma. ${ }^{23}$ Blay et $a^{24}$ reported elevation of serum IL-6 in 66 of 138 patients with advanced renal cell carcinoma, a poor prognosis in patients with elevated serum IL-6, and a poor response to IL-2 therapy in these patients. IL-6 is considered to have an important role in progression of renal cell carcinoma, consequently, suppression of serum IL-6 in mice by administration of XCHT may be beneficial in the treatment of Renca-bearing mice using IL-2.

Matsuura et $a l^{25}$ reported that intraperitoneal administration of Bupleuri Radix, Pinelliae Tuber, Scutellariae Radix, Ginseng Radix, Glycyrrhizae Radix and Zingiberis Rhizoma, which are included in XCHT as its constituents, induced serum IL-6 in mice, though, in the present study, administration of XCHT reduced 
serum IL-6 in Renca tumor-bearing mice. The discrepancy, between the present study and their results can, however, be explained by their having administered $\mathrm{XCHT}$ or its constituents to non tumor-bearing mice, or administering the agents intraperitoneally, while XCHT was given orally in our experiment.

The results obtained indicate that XCHT and IL-2 have a synergistic anti-tumor activity against renal cell carcinoma, though careful observation is needed for early detection of development of possible interstitial pneumonia in clinical application. XCHT has been used with the concept of traditional Chinese medicine for chronic active hepatitis and other inflammatory diseases, but concomitant use with IFN brought unexpected phenomena in clinical use. Clarification of the biological characteristics of XCHT and further investigation of the appropriate mode of administration based on basic and clinical studies may yield benefits in the treatment of patients with renal cell carcinoma.

Acknowledgment: This work was supported by grants from Tsumura Foundation for Medical Research.

\section{References}

1. deKernion JB, Berry $\mathrm{D}$ : The diagnosis and treatment of renal cell carcinoma. Cancer 1980; 45 (suppl7): 1947-1956

2. deKernion JB, Ramming KP, Smith RB: The natural history of metastatic renal cell carcinoma: a computer analysis. J Urol 1978; 120: $148-152$

3. Patel NP, Lavengood RW: Renal cell carcinoma: natural history and results of treatment. J Urol 1978; 119: 722-726

4. Morgan DA, Ruscetti FW, Gallo R: Selective in vitro growth of T-lymphocytes from normal human bone marrows. Science 1976; 193: $1007-1008$

5. Rosenberg SA, Lotze MT, Muul LM, Chang, AE, Avis FP, Leitman S, Linehan WM, Robertson CN, Lee RE, Rubin JT, Seipp CA, Simpson CG, White DE: A progress report on the treatment of 157 patients with advanced cancer using lymphokineactivated killer cells and interleukin-2 or high-dose interleukin-2 alone. N Engl J Med 1987; 316: 889-897

6. West WH, Tauer KW, Yannelli JR, Marshall GD, Orr DW, Thurman GB, Oldham RK: Constant-infusion recombinant interleukin-2 in adoptive immunotherapy of advanced cancer. $\mathbf{N}$ Engl J Med 1987; 316: 898-905

7. Marumo K, Muraki J, Ueno M, Tachibana M, Deguchi N, Baba S, Jitsukawa S, Hata M, Tazaki H: Immunologic study of human recombinant interleukin-2 (low-dose) in patients with advanced renal cell carcinoma. Urology 1989; 33: 219-225

8. Marumoto M, Maeda T, Kato M, Hayashi E: Anti-inflammatory action of Sho-saiko-toh. Proc Symp Soc Wakan-Yaku 1983; 16: 153-157 (in Japanese)

9. Mizoguchi Y, Sakagami Y, Okura Y, Yamamoto S, Morisawa S: Effects of Sho-saiko-to (TJ-9) in hepatitis patients and on the metabolism of arachidonic acid. In: Hosoya E, Yamamura $Y$, eds, Recent Advances in the Pharmacology of Kampo (Japanese Herbal) Medicines, International Congress Series; 854, Amster- dam, Elsevier Science Publishers B.V., 1988; 396-404

10. Ito $\mathbf{H}$, Shimura K: Studies on antitumor activity of traditional Chinese medicines (1). Gan To Kagakuryoho (Jpn J Cancer Chemother) 1985; 12: 2145-2148 (in Japanese)

11. Murphy GP, Hrushesky WJ: Murine renal cell carcinoma. J Natl Cancer Inst 1973; 50: 1013-1025

12. Yamashiki $\mathbf{M}$, Kosaka $\mathbf{Y}$, Nishimura A, Takase $\mathrm{K}$, Ichida $\mathbf{F}$ Efficacy of a herbal medicine "sho-saiko-to" on the improvement of impaired cytokine production of peripheral blood mononuclear cells in patients with chronic viral hepatitis. J Clin Lab Immunol 1992; 37: 111-121

13. Yamaoka $Y$, Kawakita $T$, Kaneko $M$, Nomoto $K$ : A polysaccharide fraction of Shosaiko-to active in augmentation of natural killer activity by oral administration. Biol Pharm Bull 1995; 18: 846-849

14. Cunliffe-Beamer TL, Les EP: The laboratory mouse. In: Poole TB, ed, The UFAW Handbook on the Care and Management of Laboratory Animals, 6th Ed, New York, Churchill Livingstone Inc, 1987; 275-308

15. Murakami K, Okajima K, Sakata K, Takatsuki K: A possible mechanism of interstitial pneumonia during interferon therapy with sho-saiko-to. Nippon Kyobu Shikkan Gakkai Zasshi (Jpn J Thoracic Diseases) 1995; 33: 389-394 (in Japanese)

16. Elias JA, Jimenez SA, Freundlich B: Recombinant gamma, alpha, and beta interferon regulation of human lung fibroblast proliferation. Am Rev Respir Dis 1987; 135: 62-65

17. Tomioka H: Kampo-Hozai induced pneumonitis. Saishin Igaku 1992; 47: 1342-1348 (in Japanese)

18. Handa K, Suzuki R, Matsui H, Shimizu Y, Kumagai K: Natural killer (NK) cells as a responder to interleukin 2 (IL 2). II. IL 2 induced interferon $\gamma$ production. J Immunol 1983; 130: 988-992

19. Hirano T, Yasukawa K, Harada H, Taga T, Watanabe Y, Matsuda T, Kashiwamura S, Nakajima K, Koyama K, Iwamatsu A, Tsunasawa S, Sakiyama F, Matsui H, Takahara Y, Taniguchi T, Kishimoto T: Complementary DNA for a novel human interleukin (BSF-2) that induces B lymphocytes to produce immunoglobulin. Nature 1986; 324: 73-76

20. Andus T, Geiger T, Hirano T, Northoff H, Ganter U, Bauer J, Kishimoto T, Heinrich PC: Recombinant human B cell stimulatory factor 2 (BSF-2/IFN- $\beta$ 2) regulates $\beta$-fibrinogen and albumin mRNA levels in Fao-9 cells. FEBS Lett 1987; 221: 18-22

21. Ikebuchi K, Wong GG, Clark SC, Ihle JN, Hirai Y, Ogawa M: Interleukin-6 enhancement of interleukin-3-dependent proliferation of multipotential hemopoietic progenitors. Proc Natl Acad Sci USA 1987; 84: 9035-9039

22. Kawano $M$, Hirano $T$, Matsuda $T$, Taga $T$, Horii $Y$, Iwao $\mathbf{K}$, Asaoku H, Tang B, Tanabe O, Tanaka H, Kuramoto A, Kishimoto T: Autocrine generation and requirement of BSF-2/IL-6 for human multiple myelomas. Nature 1988; 332: 83-85

23. Miki S, Iwano M, Miki Y, Yamamoto M, Tang B, Yokokawa K, Sonoda T, Hirano T, Kishimoto T: Interleukin-6 (IL-6) functions as an in vitro autocrine growth factor in renal cell carcinomas. FEBS Lett 1989; 250: 607-610

24. Blay JY, Negrier S, Combaret V, Attali S, Goillot E, Merrouche Y, Mercatello A, Ravault A, Tourani JM, Moskovtchenko JF, Philip T, Favrot M: Serum level of interleukin 6 as a prognosis factor in metastatic renal cell carcinoma. Cancer Res 1992; 52: 3317-3322

25. Matsuura K, Kawakita T, Nakai S, Saito Y, Suzuki A, Nomoto $\mathrm{K}$ : Role of B-lymphocytes in the immunopharmacological effects of a traditional Chinese medicine, xiao-chai-hu-tang (Shosaikoto). Int J Immunopharmacol 1993; 15: 237-243 